\title{
Education: Pathway to Empowerment for Ghanaian Women?
}

\author{
Akosua K. Darkwah
}

\begin{abstract}
Education has long been seen as crucial to women's empowerment. Increasingly, however, scholars such as Stromquist have questioned our faith in the power of education to empower women. Drawing on a survey of 600 women of three age groups in three regions of Ghana and 36 intergenerational interviews, this article makes the case that the benefits of education for women is context specific, for example when decent work in the public sector is available. This study shows that more than twice as many women aged 18-29 have had some form of education compared with those above 50. However, it finds that while all the women above 50 who worked in the formal sector worked in better paying public sector jobs, this was not the case of the women aged 18-29, almost half of whom worked in the private informal sector with more insecure incomes.
\end{abstract}

\begin{abstract}
1 Introduction
Education has long been seen as an important means by which to improve the lives of individuals, particularly women. Indeed, the importance of girls' education is such a wellentrenched view that universal primary education is one of the Millennium Development Goals. Girls' education, research shows, delivers a whole host of advantages. It has been linked with improved child health, lower rates of infant mortality and lower rates of fertility (King and Hill 1993). The extent to which this is true is rarely interrogated. This article takes the arguments of scholars such as Stromquist (2002) and Grown et al. (2005) as a starting point and asks to what extent education has made a difference in the lives of three generations of Ghanaian women. To assess differences in the lives of women, the article looks specifically at the correlation between levels of education and paid work in the public sector of the economy, with the most decent of working conditions as identified by the International Labour Organization (ILO).
\end{abstract}

The article begins with a discussion of the Ghanaian context and the ways in which access to educational institutions have been traditionally configured in a manner that limits women's opportunities for educational attainment with consequences for their access to formal sector employment. An account of the research methods used to derive the data upon which the argument is based is then provided. The argument begins with a discussion of women's educational attainment, its implications for their job opportunities in the various sectors of the economy and the earned incomes over the course of three generations.

\section{The national context: gender, education and formal sector employment in Ghana}

Formal education was introduced to Ghana in the eighteenth century by missionaries and extended in the late nineteenth century by the British colonial administration. From its inception, formal education in Ghana was gender biased. Boys were favoured over girls from both an institutional and family perspective. The state was only interested in equipping girls with an education that would make them 'better wives [for] the rising crop of educated clerks, teachers, catechists and few professional men' (Graham 
1971: 72). Families were also convinced that educating a woman was a waste of family resources because the benefits of a woman's education would accrue to her future husband. In 1890, when the British began to pay attention to formal education in Ghana, the gender ratio in primary school enrolment was 11 girls for every 100 boys (Fant 2008: 18). This disparity persisted throughout the twentieth century and is very clearly reflected in the educational attainment of the adult population. The most recent demographic and health survey conducted in Ghana in 2003 shows that: 28.2 per cent of women compared with 17.6 per cent of men have never been to school and 6 per cent of women compared with 10.5 per cent of men completed primary school; 5.2 per cent of women compared with 9.7 per cent of men completed secondary school. These numbers are most striking in terms of gender disparities in tertiary education. The number of Ghanaian men who have postsecondary education is almost three times the number of Ghanaian women -6.3 per cent of Ghanaian men compared with 2.6 per cent of women have post-secondary education. Ghanaian girls born in the twenty-first century will not be disadvantaged so far as the attainment of primary education is concerned. Gender parity in primary school enrolment was finally achieved in 2006 (Ghana Statistical Service 2007: 30). In secondary school, however, the inequalities persist. While for boys, the enrolment rates in secondary schools during the 2005/06 academic year stood at 45 per cent, the same was true for 42 per cent of girls (Ghana Statistical Service 2007: 33). The gender gap in tertiary enrolment has also improved considerably over the last two decades, although a gap still remains. At the University of Ghana, for example, female enrolment at the undergraduate level was just under 40 per cent in 2008 (University of Ghana 2008).

A second bias in the provision of education in Ghana is geographical. Bening (1990) notes that there was a systematic attempt at limiting the number of government and mission schools in the northern part of Ghana to ensure that a pool of unskilled labour was available to work in the mines and plantations in the southern part of the territory. Thus, both the first primary and secondary school were set up over a century later than the first schools had been set up in the southern part of the country. Ghana's first president, Kwame Nkrumah, attempted to remedy the situation by providing Northern Ghanaians with free education during his term of office. This and other efforts by successive governments have failed to change the educational disparity between the North and the South. In the rural Savannah, for example, net enrolment rates at primary level are below 70 per cent, even though the average in all other localities is approximately 85 per cent (Ghana Statistical Service 2007: 30). Ghanaian women who come from the northern part of the country are therefore doubly disadvantaged regarding access to education.

Women's general lack of access to education is reflected in labour force participation rates. While women dominate in the informal economy, their presence is poorly felt in the formal sector of the economy where incomes are generally higher and more secure. According to the Fifth Round of the Ghana Living Standards Survey (Ghana Statistical Service 2008), while 27 per cent of all males aged 15-64 were in waged employment, the figure for females was 8.9 per cent. In addition to their low numbers in the formal sector, women are over-represented at the lower levels of the occupational hierarchy. Data from the Women in Public Life Project conducted in 1995 showed that 95 per cent of the secretaries and all the receptionists in the civil service were women. Meanwhile, there was no female Chief Director as at 1995 and only 10.9 per cent of the directors were female (Awumbila 2000: 53). By 2003, the situation had improved only marginally; two out of the 11 chief directors of ministries in the country were women (Ministry of Women and Children's Affairs 2004: 35).

\section{Methodology}

Our discussion draws primarily on a survey of 600 adult women in both rural and urban communities in three regions of Ghana: Northern, Ashanti and Greater Accra. The survey was conducted in two districts (one rural, one urban) in each of the three Regions. The communities selected in the urban areas represented different income groups. Women were selected randomly from three age groups: 18-29; 30-49 and 50 and over. The number of women sampled in each of these three age groups was in-keeping with the fact that the Ghanaian population is a relatively young population. Thus, the 18-29 year-olds 
Table 1 Educational levels of respondents (\%)

\begin{tabular}{lllll}
\hline Educational level & $\mathbf{1 8 - 2 9}$ years & $\mathbf{3 0 - 4 9}$ years & $\mathbf{5 0 +}$ years & Total \\
\hline None & 23.5 & 40.5 & 69.4 & $\mathbf{4 4 . 5}$ \\
Informal & 2.1 & 4.2 & 1.7 & $\mathbf{2 . 6}$ \\
Primary & 15.7 & 13.5 & 5.8 & 11.7 \\
Middle/junior secondary school & 32.6 & 24.5 & 13.2 & 23.4 \\
Secondary & 18.1 & 8.0 & 0 & 8.6 \\
Vocational/technical & 2.0 & 3.4 & 5.8 & 3.7 \\
Apprenticeship & 1.6 & 0.4 & 0 & 0.7 \\
Tertiary & 1.2 & 0.9 & 0 & 0.7 \\
Other tertiary & 2.9 & 4.6 & 4.1 & 3.9 \\
Source Fieldwork, 2008. & & & & \\
\hline
\end{tabular}

constituted 40.3 per cent of the sample, the 30-49 year-olds constituted 39.5 per cent and those aged over 50 constituted 20.2 per cent. Since it was impossible to use a survey to track the trajectories of particular women in their attainment of an empowered status in various aspects of their life, we conducted in-depth interviews of three generations of women (grandmother, mother and daughter). A total of 12 sets - four from each Region - were conducted. The in-depth interviews were to illuminate change processes and nuances and foreground issues such as national context and local specificities, which could not be addressed with survey questions. In this article, I draw largely on the findings of the survey and buttress the survey findings with interview material where possible.

The first thing to note about the literacy levels of the women in our sample is the unsurprising fact that levels of illiteracy are high among Ghanaian women. Two-fifths of the sample have not received any form of education at all. In this sample, one-quarter of the women, once they were provided with the opportunity to go to school acquired what is considered to be basic level education (six years of primary and three years of middle school). More women dropped out of school with only primary education (11.7 per cent) than those who spent extra years acquiring secondary education (8.6 per cent). Less than one per cent of the women in this sample have a tertiary degree, although almost
4 per cent of the women in the sample have acquired some post-secondary training such as computer skills training.

A woman's access to education also depended on when she was born. Table 1 shows that there is a negative correlation between age and access to education. Indeed, the percentage of women above the age of 50 who had not acquired any education at all was three times higher than that for women aged 18-29. The percentage of women who had acquired the various levels of education was lowest among those aged above 50 and highest among those aged 18-29. The only exception was with vocational/technical education. Here, the scenario was reversed. The percentage of women among the youngest cohort who had this level of education was far lower than those among the oldest. Another important point to note is the fact that apprenticeship training, although limited, is confined to women under the age of 50, particularly those aged 18-29. Apprenticeship training is seen as a way out if general education fails. Many mothers and daughters we interviewed had learned one of the female dominated trades such as hairdressing and dressmaking. However, a number were not practising their trades and were instead involved in petty trading and farming. In several cases, they said they had no capital to buy the equipment with which to ply their trade. Therefore for artisanal training, training was not sufficient. A sponsor was also needed to get the vocation started. In the case of one woman who 
had trained as a baker in the Ashanti Region, her teacher had to provide her with flour and sugar on credit for several years and her own mother had provided the money for the oven she used for baking.

There are two important points to note about the statistics on education. First, although threequarters of the women aged 18-29 had been to school, it is important to keep in mind that onequarter was unable to attend because of the prevailing socioeconomic circumstances during the period when they were of school-going age. Those in our sample aged 18-29 grew up during the height of the implementation of the structural adjustment programme in the 1980s, the implications of which among other things meant the lack of subsidies for education. Our interviews in rural Accra highlight what such arrangements for schooling meant for young rural girls. Adikuor is a 23-year-old mother of one who grew up in a village about an hour's drive east of the capital city of Ghana. Adikuor's parents put her in school when she was six and although neither of them had completed their schooling (her father dropped out in his first year of secondary school, while her mother dropped out in her fifth year of primary school), they had high hopes for Adikuor. She would be the first female in the family to earn, at the very least, secondary education. All was well until Adikuor turned nine. That year her father died and her mother, who was a food crop farmer, was incapable of single-handedly putting her two children through school. She, like many other African families who faced the dilemma of choosing between a daughter and a son's education, decided to keep Adikuor's brother in school. Adikuor was sent off to her paternal aunt in Lomé in neighbouring Togo as a foster child. Fostering is an old practice in Ghana. Indeed, anecdotal evidence suggests that many Ghanaians are raised by relatives and although recent material on the incidence of fostering is hard to come by, earlier studies such as that conducted by Aryee (1975) of 1,337 households in Accra found that 63.1 per cent of the fathers and 44.9 per cent of the mothers had at least one child living elsewhere.

In our interviews, we came across several women in the mother's generation who had also grown up as foster children. The stories of these women suggest that fostering does not augur well for girls. In one case in northern Ghana, the grandmother in our interviews sent each of her three daughters to extended family members who failed to put them in school while she put two of her own sons through school. The story of Adikuor also highlights the disadvantages of fostering as far as girls' educational attainment is concerned. When Adikuor was sent off to her aunt, there was a tacit agreement between her mother and her aunt that her aunt would take good care of her, including putting her in school. Instead, Adikuor's aunt put her to work as her shop assistant so she could help to raise the monies with which her male cousins could be put through school. Adikuor worked diligently with the hope that eventually her aunt would put her through school. After a decade of waiting in vain, Adikuor returned to Ghana with nothing to show for her years abroad. Now married with a fouryear-old daughter, Adikuor's career prospects are limited. She spends her days helping her motherin-law who makes doughnuts for a living, and now hopes that her husband will be able to put together the resources to put her through an apprenticeship training programme in hairdressing. Not being able to read, however, means that Adikuor will not be able to write the National Vocational Technical Institute's qualifying examination which is necessary if she intends to ever work in the formal sector as a hairdresser. To be able to earn a reasonable living in the informal economy as a self-employed hairdresser, Adikuor would have to purchase the basic equipment needed to run a hair salon, which in the current circumstances seems impossible. As it stands, her best option would be to work in the private informal economy for subsubsistence wages and no job security. Like her mother, the food crop farmer, and her grandmother, the priestess, Adikuor will have to eke out a living for herself and her family.

Second, the most significant change across the three generations of women as far as education is concerned is the increasing numbers of women with education. While only a few grandmothers had gone to school, many more mothers and daughters had been to school. This finding was replicated in our intergenerational interviews across the country, but was most striking in the Northern Region. There, three out of four mothers and all four grandmothers had no formal education. In Northern Ghana, in particular, however, education is seen as crucial 
Table 2 The importance of education for employment

\begin{tabular}{|c|c|c|c|c|c|c|}
\hline \multirow[t]{2}{*}{ Terms of employment } & \multicolumn{2}{|c|}{ None } & \multicolumn{2}{|c|}{ Primary-high school } & \multicolumn{2}{|c|}{ Total } \\
\hline & Freq. & (\%) & Freq. & $(\%)$ & Freq. & $(\%)$ \\
\hline Formal sector employees & 3 & 1.7 & 54 & 21.1 & 57 & 100 \\
\hline Self-employed with employees & 25 & 14.3 & 40 & 15.6 & 65 & 100 \\
\hline Self-employed without employees & 130 & 74.3 & 134 & 52.3 & 264 & 100 \\
\hline Apprentices & 4 & 2.3 & 16 & 6.3 & 20 & 100 \\
\hline Agricultural day labour & 4 & 2.3 & 1 & 0.4 & 5 & 100 \\
\hline Unpaid work on family farm/enterprise & 3 & 1.7 & 3 & 1.2 & 6 & 100 \\
\hline Other & 6 & 3.4 & 8 & 3.1 & 14 & 100 \\
\hline Total & 175 & 100 & 256 & 100 & 431 & 100 \\
\hline
\end{tabular}

for improving one's life. This is related to the fewer economic options available when compared with the Ashanti and Greater Accra Regions. In our interviews at Damongo (capital of a district in the Northern Region), Azara, a mother who had had the benefit of tertiary education and formal sector work through her active engagement in the Catholic Church, was a good example of the value of education for intergenerational class mobility. Northern Ghanaian women in the second generation were acutely aware of the ways in which their lack of education had affected their life chances. These mothers had therefore been instrumental in ensuring that their daughters received the education they had been denied. Sakina, a 51-year-old mother in Tamale (capital of the Northern Region), noting the importance of education for her children, daughters included, said,

\section{Even though I didn't get the opportunity to go to school, I entreat my kids to take their education seriously. Even though I did not go to school, all my kids (two boys and five girls) have had the opportunity to go to school.}

Muni, also from the Northern Region describes her mother's instrumental role in ensuring that her children went to school:

My father didn't want us to go to school because especially for the boys he wanted them to help him on the farm, but there was a lot of discussion in the community about the importance of education so that was when my mother said she wanted us to go to school, so through my mother's efforts, we went to school.

These mothers went to great lengths to ensure that nothing stood in the way of their daughter's educational success. Two of the three daughters whose mothers had not gone to school exempted them from house chores completely so as to ensure that they had all the time they needed to study. In our discussions of employment however, it will become clear that the significance of education for employment has changed over the years, for the worse.

\subsection{The relationship between education and employment}

We will now explore the relationship between education, generation and terms of employment to assess the extent to which the educational levels of women translates into economic empowerment as suggested in the literature which we measure here as access to decent work as defined by the ILO and provided in the Ghanaian context by work in the public formal sector.

Table 2 affirms the importance of education for employment. It shows clearly that access to formal salaried employment is a function of whether or not one has acquired an education. While 21 per cent of those with some amount of education worked in the formal economy, the 
Table 3 Generational differences in terms of employment

\begin{tabular}{|c|c|c|c|c|c|c|c|c|}
\hline \multirow[t]{2}{*}{ Terms of employment } & \multicolumn{2}{|c|}{$18-29$ years } & \multicolumn{2}{|c|}{$30-49$ years } & \multicolumn{2}{|c|}{$50+$ years } & \multicolumn{2}{|c|}{ Total } \\
\hline & Freq. & (\%) & Freq. & $(\%)$ & Freq. & (\%) & Freq. & $(\%)$ \\
\hline Agricultural day labour & 1 & 0.7 & 4 & 2.0 & 0 & 0.0 & 5 & 1.2 \\
\hline Non-agricultural day labour & 0 & 0.0 & 1 & 0.5 & 0 & 0.0 & 1 & 0.2 \\
\hline Worker (contractual wage based) & 1 & 0.7 & 0 & 0.0 & 1 & 1.3 & 2 & 0.5 \\
\hline Salaried employee (permanent/regular) & 22 & 15.0 & 22 & 10.7 & 4 & 5.0 & 48 & 11.1 \\
\hline Salaried employee (irregular) & 5 & 3.4 & 2 & 1.0 & 2 & 2.5 & 9 & 2.1 \\
\hline Self-employed (employer) & 17 & 11.6 & 34 & 16.5 & 14 & 17.7 & 65 & 15.0 \\
\hline Self-employed (no employees) & 70 & 47.6 & 136 & 66.0 & 58 & 73.4 & 264 & 60.9 \\
\hline Unpaid work on family farm & 3 & 2.0 & 3 & 1.5 & 0 & 0.0 & 6 & 1.4 \\
\hline Unpaid work in family enterprise/business & 8 & 5.4 & 3 & 1.5 & 1 & 1.3 & 12 & 2.8 \\
\hline Apprenticeship (salaried/non-salaried) & 19 & 13.0 & 1 & 0.5 & 1 & 1.3 & 21 & 4.8 \\
\hline Total & 146 & 100 & 206 & 100 & 79 & 100 & 433 & 100 \\
\hline
\end{tabular}

same was true for less than 2 per cent of uneducated women. With regard to agricultural labour, an uneducated woman was five times more likely to work on a farm as an educated woman, although the numbers were not high enough to make conclusive findings. In assessing the relationship between education and entry into 'decent' work, which we defined as public formal employment, it was quite clear that education allowed entry into this work. Some 21 per cent of women with some education as opposed to 2 per cent of women with no education were involved in work, which satisfied some of the indicators of decent work. However, for workers in the informal economy, the relationship between education and decent work was not so clear cut; 52 per cent of women with some level of education as opposed to 74 per cent without any education were self-employed without employees.

Age also makes a difference to whether or not a woman is likely to work as a salaried employee in the formal economy, with all the benefits that accrue to workers in such jobs. As evident in Table 3, the percentage of women aged 18-29 who were salaried employees was three times higher than that of women aged 50 and above. Conversely, 73 per cent of women aged over 50 were in self-employment without employees, as opposed to 66 per cent aged 30-49 and 48 per cent aged 18-29. The patterns were similar with

Table 4 Generational differences in kinds of salaried employee positions

\begin{tabular}{lccccccccc}
\hline & \multicolumn{2}{c}{$\mathbf{1 8 - 2 9}$ years } & \multicolumn{2}{c}{$\mathbf{3 0 - 4 9}$ years } & \multicolumn{2}{c}{$\mathbf{5 0 +}$ years } & \multicolumn{2}{c}{ Total } \\
& Freq. & $\mathbf{( \% )}$ & Freq. & $\mathbf{( \% )}$ & Freq. & (\%) & Freq. & (\%) \\
\hline Government & 8 & 27.6 & 14 & 60.9 & 5 & 100 & 27 & 47.4 \\
Private formal & 8 & 27.6 & 2 & 8.7 & 0 & 0.0 & 10 & 17.5 \\
Private informal & 13 & 44.8 & 7 & 30.4 & 0 & 0.0 & 20 & 35.1 \\
Total & 29 & 100 & 23 & 100 & 5 & 100 & 57 & 100 \\
Source Fieldwork, 2008. & & & & & & & & &
\end{tabular}


Table 5 Employer and income (Ghana cedis)

\begin{tabular}{lllllllll}
\hline & $<58$ & $\mathbf{5 9 - 1 0 0}$ & $\mathbf{1 0 1 - 1 4 9}$ & $\mathbf{1 5 0 - 1 9 9}$ & $\mathbf{2 0 0 - 2 9 9}$ & $\mathbf{3 0 0 - 3 9 9}$ & $\mathbf{4 0 0 - 4 9 9}$ & $>\mathbf{5 0 0}$ \\
\hline Government & 2 & 3 & 2 & 4 & 9 & 3 & 1 & 3 \\
Private formal & 4 & 3 & 0 & 0 & 2 & 1 & 0 & 0 \\
Private informal & 10 & 4 & 0 & 1 & 0 & 0 & 0 & 0 \\
Totals & 16 & 10 & 2 & 5 & 11 & 4 & 1 & 3 \\
Source Fieldwork, 2008. & & & & & & & &
\end{tabular}

self-employment with employees, with women over 50 having the highest percentages and women 18-29 having the lowest figures. Not surprisingly, apprenticeships were largely the reserve of women aged 18-29, as was unpaid work. More than half of the women who worked for no pay in our sample were aged 18-29.

Agricultural labour was largely the preserve of the middle generation with 83 per cent of the women in agricultural labour were aged 30-49.

To further explore the significance of our findings that younger women were more likely to be employed in the formal economy than older women, we examined differences in the kinds of employer that the employees in the sample had. As shown in Table 4, all the women above the age of 50 were employed by state institutions. None of them were employed in the private formal or informal sectors. For the women aged 30-49, 60 per cent were employed in state institutions, 30 per cent in the private formal sector with only 9 per cent employed in the private informal sector. For women aged $18-29$, only 28 per cent were employed by the government, another 28 per cent by the private formal sector and 45 per cent by the private informal sector. These figures are due to the shrinkage in public sector employment since the 1980s' economic liberalisation policies. This has implications for acquiring decent work and suggests that for younger women, educational levels on their own were no guarantee for securing this. Table 5 demonstrates this. All three people who earn 500 Ghana cedis and above are government employees, while 19 people earning 200 Ghana cedis and above are in government (16) and private formal (3) employment. Conversely, of the 16 whose monthly earnings are below the government announced minimum wage, ten have employers in the private informal sector. All of the 15 employees with employers in the private informal sector earned less than 200 Ghana cedis. These findings are supported by the literature on the informalisation of work and informal labour markets in Ghana, which argues that employees in the informal economy are in some of the most insecure and poorly remunerated jobs (Heintz 2005; Tsikata 2008).

Tables 2-5 together tell an important story about the changing significance of the value of education. While clearly many more of the women aged 18-29 as compared with those aged above 50 have had formal education, the impact of this education on women's ability to enjoy the benefits of decent work has not been similar. The women aged 18-29 are far more likely to work in the private formal and informal sectors of the economy as compared with the educated women aged 50 and above, all of whom worked in the public formal sector. Yet, workers in the private sector are not remunerated as well as workers in the public sector.

This story is also clearly reflected in the lives of Azara and her daughter, Alima, one of the four families we interviewed in the Northern Region. Azara is aged 49, a staunch Catholic and married. She grew up in Damongo. Neither of her parents ever attended school; her father was a farmer and she describes her mother as a housewife. Her mother was one of four wives with whom the father had a total of 26 children (7 male and 19 female). Only four girls out of the 19 ever attended school and Azara is the most highly educated of these. She started her career as a typist at the Ministry of Health in 1980 and one year ago she earned a diploma in secretarial studies and management, after which she was promoted to her current position as an executive officer. 
Azara was educated through perseverance on her part. Her father had many children and could not afford to educate them all. Azara, however, was very determined to go to school, even though she was growing up at a time when many thought that girls did not need to be educated. She recalls periods when she had to stay away from school but her insistence on going was critical to ensuring that resources were found to return her. At one point, even though it was her father who put her there, he gave Azara in marriage to an older man when she was still at school; she fought against this and the proposed marriage did not take place. Her father then decided to no longer maintain her in school and her mother agreed to take up responsibility for her education. Azara for her part helped her mother by collecting and selling firewood and making garri (coarsely ground cassava flour). All that hard work paid off. Azara's steady source of income from her work in the public sector has enabled her to care for her children, to acquire land and to build a house. She also believes that her ability to work has played a major role in the success of her marriage to her husband with whom she has two sons and three daughters. The oldest of her daughters is 29-year-old Alima. Alima was brought up in the capital city of a largely rural district, but she has also spent some years in Tamale as well as southern Ghana because of her education. Although she would have liked to go on to university after secondary school, she did not do well enough on the qualifying examination. Instead, at a series of secretarial schools she gained a National Vocational and Technical Institute (NVTI) certificate in secretarial studies, a diploma in business and secretarial studies and a Higher National Diploma in secretarial and management studies. Alima, it seems, is all set to follow in her mother's footsteps. However, although Alima is starting her working life with the qualifications her mother just recently earned, the possibilities for Alima working her way up the professional track like her mother is doubtful. Currently, in spite of the fact that Alima has more educational qualifications than her mother did at the start of her career, Alima is unemployed and looking for work that would allow her to use the skills she has acquired through training. The possibilities of this happening in the near future are not good, although with their connections in the church, she might be able to find something. Although the public sector, as we have already shown, provides the most secure of jobs and better income, Alima cannot look to this sector for employment, since it has been shrinking over the years. In addition, the district capital in which she lives does not offer many options for secretarial work in the private formal or informal sector and even if she had these options, they would not guarantee her the security that her mother having worked for almost 30 years in the public sector has had. Not having found the kind of work that she is looking for, Alima has chosen to acquire more education in the hope that it will improve her job prospects, preferably in the public sector.

\section{Conclusion}

This study affirms the importance of women's education for determining whether a woman works in the public sector or is able to run a business that employs others in the Ghanaian context. While 94.5 per cent of the women who worked in the public sector were educated, this was true of 62 per cent of those who were selfemployed and had employees. While the education of girls can therefore be acknowledged as a key ingredient in producing empowered women, this study also suggests that conventional empowerment initiatives, which assume that providing education for girls is all it takes to produce empowered women, are problematic. Context is key in determining whether or not an educated girl will grow up to become an empowered woman. As clearly shown in this study, the provision of universal primary education without concomitant attention to the provision of jobs that satisfy the conditions of decent work as stipulated by the ILO hinders educated women's efforts at gaining control over financial resources. Two decades after empowerment entered development discourse as a guiding principle or goal of development work, this study shows that we need a multi-pronged approach to empowering women around the world. Education, in and of itself is not good enough. It needs to be matched with better access to public sector jobs or laws that ensure that private formal and informal sector jobs provide decent work as defined by the ILO. 


\section{References}

Aryee, A. (1975) 'A Study of Parent-Child Separation in Accra', Legon Family Research Papers 4: 85-91

Awumbila, M. (2000) 'Women and Gender Equality in Ghana: A Situational Analysis', in D. Tsikata (ed.), Gender Training in Ghana: Politics, Issues and Tools, Accra: Woeli Publishing Services

Bening, R. (1990) A History of Education in Northern Ghana 1909-1976, Accra: Ghana Universities Press

Fant, E. (2008) 'Education and Girl Child Empowerment: The Case of Bunkpurugu/ Yunyoo District in Northern Ghana', thesis presented to the Faculty of Social Studies, University of Tromsø, Norway for a Master of Philosophy in Indigenous Studies

Ghana Statistical Service (2008) Ghana Living Standards Survey 5, Accra: Ghana Statistical Service

Ghana Statistical Service (2007) Pattern and Trends of Poverty in Ghana, Accra: Ghana Statistical Service

Graham, C. (1971) The History of Education in Ghana: From the Earliest Times to the Declaration of Independence, Accra: Ghana Publishing Corporation

Grown, C.; Gupta, R. and Kes, A. (2005) Taking Action: Achieving Gender Equality and Empowering Women, UN Millennium Project: Task Force on
Education and Gender Equality,

Sakinatp://www.unmilleniumproject.org/ documents/Gender-complete.pdf (accessed 5 February 2009)

Heintz, J. (2005) Gender, Employment and Poverty in Ghana, background paper prepared for the 2005 Progress of the World's Women, New York: UNIFEM

King, E. and Hill, M. (eds) (1993) Women's Education in Developing Countries: Barriers, Benefits and Policies, Baltimore: Johns Hopkins for the World Bank

MOWAG (2004) Ghana's Second Progress Report on the Implementation of the African and Beijing Platform of Action and Review Report for Beijing +10, Accra: Ministry of Women and Children's Affairs

Stromquist, N. (2002) 'Education as a Means for Empowering Women', in J. Parpart, S. Raj and K. Staudt (eds), Rethinking Empowerment: Gender and Development in a Global/Local World, London: Routledge

Tsikata, D. (2008) 'Informalisation, the Informal Economy and Urban Women's Livelihoods in sub-Saharan African since the 1990s', in S. Razavi (ed.), The Gendered Impacts of Liberalisation: Towards Embedded Liberalism, New York: Routledge

University of Ghana (2008) Basic Statistics, 2008, Legon: University of Ghana 